This is an electronic reprint of the original article. This reprint may differ from the original in pagination and typographic detail.

Author(s): Laasasenaho, Kari; Lensu, Anssi; Rintala, Jukka

Title: $\quad$ Planning land use for biogas energy crop production: The potential of cutaway peat production lands

Year: $\quad 2016$

Version:

Please cite the original version:

Laasasenaho, K., Lensu, A., \& Rintala, J. (2016). Planning land use for biogas energy crop production: The potential of cutaway peat production lands. Biomass and Bioenergy, 85(February), 355-362. https://doi.org/10.1016/j.biombioe.2015.12.030

All material supplied via JYX is protected by copyright and other intellectual property rights, and duplication or sale of all or part of any of the repository collections is not permitted, except that material may be duplicated by you for your research use or educational purposes in electronic or print form. You must obtain permission for any other use. Electronic or print copies may not be offered, whether for sale or otherwise to anyone who is not an authorised user. 


\title{
Planning land use for biogas energy crop production: The potential of cutaway peat production lands
}

\author{
Kari Laasasenaho a,* ${ }^{\text {, Anssi Lensu }}{ }^{\mathrm{b}}$, Jukka Rintala ${ }^{\mathrm{c}}$ \\ ${ }^{a}$ University of Jyvaskyla, Department of Chemistry, P.O. Box 35, FI-40014 University of Jyvaskyla, Finland \\ ${ }^{b}$ University of Jyvaskyla, Department of Biological and Environmental Science, P.O. Box 35, FI-40014 University \\ of Jyvaskyla, Finland \\ ${ }^{c}$ Tampere University of Technology, Department of Chemistry and Bioengineering, PO Box 527, FI-33101 \\ Tampere, Finland \\ *Corresponding author. Tel: +358400527038; fax: +358-14-260-2501. \\ E-mail addresses: kari.laasasenaho@jyu.fi (K. Laasasenaho); anssi.lensu@jyu.fi (A. Lensu); jukka.rintala@tut.fi (J. \\ Rintala).
}

\begin{abstract}
Each year, thousands of hectares of peatland that had been harvested are being released in Finland, which can offer an opportunity to increase energy crops and attain the bioenergy targets for non-agriculture lands. In this study, the Geographic Information System (GIS) method was used to improve the assessment of decentralized renewable energy resources. The amount of peat production lands and future cutaway areas for energy crop production was calculated as a case study by using ArcGIS and the Finnish Topographic database. There are almost 1,000 $\mathrm{km}^{2}$ of peat production lands in Finland, and theoretically, approximately $300 \mathrm{~km}^{2}$ of cutaway peatlands could be used for energy crops after 30 years. The dry biomass yield of reed canary grass (Phalaris arundinacea) or timothy-fescue grass (mix of Phleum pratense and Festuca pratensis) could be higher than $100 \mathrm{Gg} \mathrm{y}^{-1}$ in these lands indicating methane potential of approximately
\end{abstract}


$300 \mathrm{GWh}$. The exhausted peat production areas in the western region of Finland have significant potential for use for energy crops; North and South Ostrobothnia account for almost $45 \%$ of the total peat production land. A future goal could be to use the cutaway peat production lands more efficiently for bioenergy to mitigate climate change. Since the use of wastelands (including peatlands) are being considered in Europe as a way to avoid competition with food production, the GIS method used in the study to identify suitable peat lands could be applicable to biomass resource studies being conducted in many countries.

Keywords:

GIS

Wasteland

Bioenergy

Phalaris arundinacea

Phleum pratense

Festuca pratensis

\section{Introduction}

Recently, decentralized energy systems and the production of renewable energy have been under development in many countries. Producing renewable energy from biomass is one solution for replacing fossil fuels and mitigating the associated greenhouse gas emissions. Many agro biomass plants, such as varieties of grasses and maize, are suitable for producing bioenergy, through combustion, gasification, pyrolysis [1], and biogas technology [2]. Traditionally, agro biomass is grown on agricultural lands. However, the first-generation energy plants are 
competing with food production [3]. One solution for avoiding the competition is to grow energy plants on non-agriculture areas such as cutaway peat production lands. Versatile wastelands have been studied in India to promote Jatropha curcas for biodiesel [4]. Additionally, in Sweden, energy willow has been studied in landfill areas, and in Latvia, abandoned farmland has been estimated for bioenergy production $[5,6]$.

\subsection{Peatland utilization and cutaway dynamics}

Peatlands are areas that have a naturally accumulated peat layer at the surface soil. Peat consists of partially decomposed organic material, originating mostly from plants, which has accumulated under oxygen deficiency, waterlogging, acidity, and nutrient deficiency conditions. Worldwide, peatlands cover almost 4 million $\mathrm{km}^{2}$. Most peatlands are in pristine condition, but approximately 0.5 million $\mathrm{km}^{2}$ have been used in agriculture, forestry, and peat extraction. The biggest peatlands are located in North America, Asia, and Europe. Russia, Canada, and Northern Europe have large peat resources in the Boreal region. In 2008, the total amount of peat consumed as fuel worldwide was 17.3 million $\mathrm{Mg}$ [7]. Finland is the most densely mired country and the biggest peat producer in the world. The total peatland is about 9 million ha, and about $0.8 \%$ (70,000 ha) of the total peatland is under production in Finland [7-9]. Peat can be used for energy generation or environmental peat products (e.g., horticulture, bedding material, and compost ingredient). Most harvested peat is used as energy in combustion plants [7,10]. In 2013, peat energy accounted for about $4 \%$ of the total energy consumption in Finland when the total energy consumption was $1.34 \times 10^{6} \mathrm{TJ}[11]$. 
Land used to produce peat usually undergoes many steps. The preparation phase, including permission and water drying, lasts from 11 to 15 years in Finland, while the peat production phase itself can last from 15 to 30 years (Fig. 1). The most popular peat form, milled peat, is based on a process in which the surface layer to a depth of $10-40 \mathrm{~mm}$ is collected with tractors after the turning and drying process. Another form, sod peat, is produced by pressing the peat into cylindrical sods. The peat in peat production areas is on average $2 \mathrm{~m}$ thick, but the thickness depends on the topography. There are usually 40 to 50 peat harvesting days annually in Finland [12] during which an approximate $10 \mathrm{~cm}$ thick layer is removed every year (with 20-30 production years). Peat production has negative environmental impacts, such as positive global warming effect (slowly renewable energy source) and loss of nature habitat and water quality. Production is regulated by several laws and is implemented as environmentally friendly as possible in Finland [7,12].

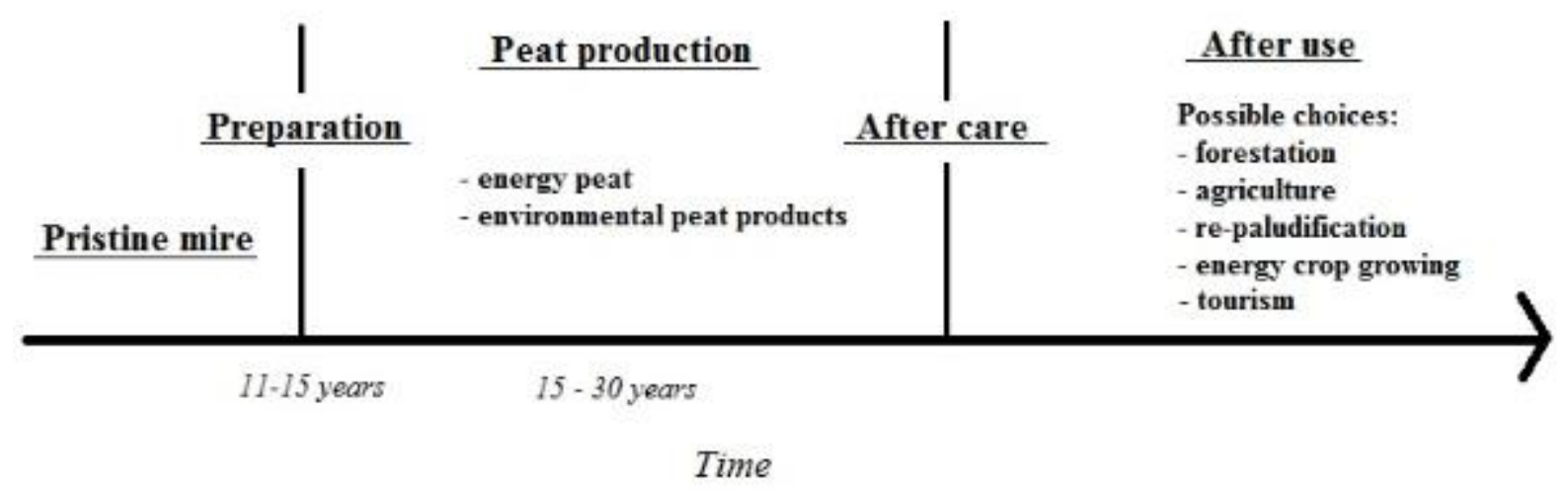

Fig. 1 - Peat production land dynamics from pristine mire to the after-use phase in Finland (modified from Salo and Savolainen [12]).

Each year, 2,000-5,000 hectares are released from production since the production phase usually lasts for only a few decades [12,13]. It is estimated that about 44,000 hectares of peatland will be 
reclaimed by 2020 [14]. After-use of peat production lands may include forestry, agriculture, nature conservation, wetland, and tourism (Fig. 1). The most common after-use method in Finland is forestation. Another choice for cutaway peatlands is growing energy crops and producing energy. However, several factors affect the choice of after-use methods, e.g., the need to pump water, soil type, land owners' interests, and possible transportation distance between the cutaway land and the final use of the biomass.

Different sections of the peat production area are not released from production at the same time, which should be taken under further consideration before any decision is made about their afteruse [12]. Furthermore, acid sulfate soils as well as topography and groundwater levels are essential factors to consider. Acid sulfate soils can cause acidification if land use methods such as ditch digging oxidize otherwise anoxic soil. When sulfide is oxidized, it can start a reaction that leads to the formation of sulfuric acid. Acidification can be prevented by liming the soil and carefully planning land use [15]. After-use forms of cutaway lands are not limited by law $[12,13]$. The minimum analysis suggested for mineral subsoils are $\mathrm{pH}$, sulfur content, and fine material $(<0.06 \mathrm{~mm})$ percentage [16]. According to Salo and Savolainen [12], especially during the 1990s much of the peat production area moved to the after-use phase when the oldest peat production lands were exhausted in Finland.

\subsection{Energy crops and increased bioenergy production on cutaway peatlands}

Cutaway peat production areas can be used to grow energy crops if the natural water level can be kept low enough with ditches. If the water level has been adjusted with pumps, the hydrological conditions are usually too wet for agriculture. In that case, a suitable after-use method is wetland 
or mire regeneration [12]. About 26-42\% of cutaway peat production lands are suitable for agriculture or energy crop production depending on the boulder-poor areas [16]. The biggest peat producer in Finland, Vapo, used approximately $30 \%$ of the cutaway lands in practice for agriculture or energy crops in 2010 [17]. Nevertheless, the use of fertilizer is necessary in many cases to ensure the normal growth of the plants, biomass production, and proper soil fertility [12]. Salo [13] estimated that most likely the portion of mire regeneration and wetland as an after-use method is increasing, because currently the oldest and deepest (pool-forming) peat production sites are more intensively being released from production.

If agricultural demands are achieved, reed canary grass (RCG, Phalaris arundinacea) can be grown on cutaway peatlands $[18,19]$ as well as timothy grass (Phleum pretense). According to a plant experiment, RCG is the most high-yielding grass species in peatlands [20] with yields of 5 to ca $12 \mathrm{Mg}_{\mathrm{dry}} \mathrm{ha}^{-1} \mathrm{yr}^{-1}$ when fertilization and liming are optimal [20,21]. However, in practice, the yield is usually closer to $5 \mathrm{Mg}_{\mathrm{dry}} \mathrm{ha}^{-1} \mathrm{yr}^{-1}$ because of e.g. frostbite and temporary flooding [22]. In addition, ditch loss decreases the biomass yield because of the intensive drainage process. There are usually $500 \mathrm{~m}$ of ditches per hectare of peat production land [23]. According to Järveoja et al. [24], reed canary grass is the best after-use alternative if GHG (greenhouse gas) emissions, related to soil use and biomass combustion, are considered. Similar results were calculated by Kirkinen et al. [25].

In 2009, there were about 20,000 ha of RCG cultivation on cutaway lands and agricultural fields in Finland. RCG was a promising plant species when renewable energy was the focus; however, because technical difficulties (the need to separate the feeding line into the combustion chamber) 
appeared in combustion plants, RCG farming has decreased significantly since 2010 [26]. Instead of combustion, RCG can be used as a feedstock in biogas plants that have methane potential ranging from 246 to $430 \mathrm{dm}^{3} \mathrm{~kg}^{-1} \mathrm{VS}[3,27,28]$. Cutaway peat production areas could offer opportunities for neighboring farmers to make farm-scale biogas plant investments more profitable when local available feedstock resources increase. Peat production areas are usually large units (from tens to even hundreds of hectares) and logistically easily accessible [12]. In addition, farmers have harvesting equipment for energy crops. Co-digestion of crops with cow manure can stabilize the process and increase the amount of biogas and even decrease farmingassociated greenhouse gases [29]. For instance, 50 ha of cutaway peatland for energy crops would theoretically offer an $815 \mathrm{MWh}$ gross energy yield for a farm-scale biogas plant $\left(5 \mathrm{Mg}_{\mathrm{dry}}\right.$ $\mathrm{ha}^{-1} \mathrm{yr}^{-1}$ with a methane yield of $326 \mathrm{dm}^{3} \mathrm{~kg}^{-1} \mathrm{TS}$ [28]). Consequently, it is essential to recognize cutaway peat production lands as part of potential wasteland for energy crop production to increase decentralized renewable energy production.

The energy crop resources of cutaway peatlands can be estimated by using Geographic Information Systems (GISs). GIS-based methods have been used to calculate regional biogas potential [6,30-34]. Spatial distribution of biomass resources and the most effective utilization location for energy production can be investigated by combining location optimization methods and GIS. Optimization methods have been used to calculate the best supply chains of biofuels [35]. When GIS and location optimization methods are combined, there are many advantages such as better visualization in solving problems [36].

The objective of this study was to apply GIS-based methods to calculate the area of peat production land in Finland. Based on the area, the future after-use potential of cutaway peatlands 
for energy crop production can be assumed by using previous studies and knowledge of biomass yields in peatlands. This type of research has not been conducted in such wide context before, and the results of this study can offer knowledge for policymakers and energy businesses stakeholders to develop bioenergy-based commercial activity in rural areas. The GIS method used in the study can be applied in other countries, if biomass resources must be allocated. This study did not include greenhouse gases or energy inputs related to energy crop production (harvesting, transportation, etc.).

\section{Materials and methods}

\subsection{Spatial analysis of peat production in ArcGIS}

The GIS-based analysis of peat production in Finland was performed with the ArcGIS v. 10.2 ArcMap program. The peat production sites in Finland were observed with the MapSite service (produced by National Land Survey of Finland, NLS) on a scale of 1:200,000 (human-made objects were updated in 2013). The maps used in this study were made by NLS and are in the Topographic database (@ NLS, 2014 supplied as $12 \mathrm{~km} \times 12 \mathrm{~km}$ map tiles). The map layer containing all types of nature was added to a map project in the ArcGIS program for further analyses. The polygons representing areas under organic soil mining (class value 32113 in topographic database) were extracted with the ArcGIS Selection tool into new map layers. All map tiles containing organic soil mining polygons were then combined together using the Merge tool.

The resulting map layer contained all peat production areas in Finland, and they were then defined by commonalities with the Intersection tool using Finnish municipality and region maps 
(C) NLS, 2014, the names and the locations of the regions are presented in Fig. 2). Then the surface area of the regional peat production lands was calculated by using the Calculate Areas (in the Spatial Statistics tools) and Summarize tools. All calculations based on the areas were made with the Field calculator in the attribute table and Microsoft Excel v. 2010.

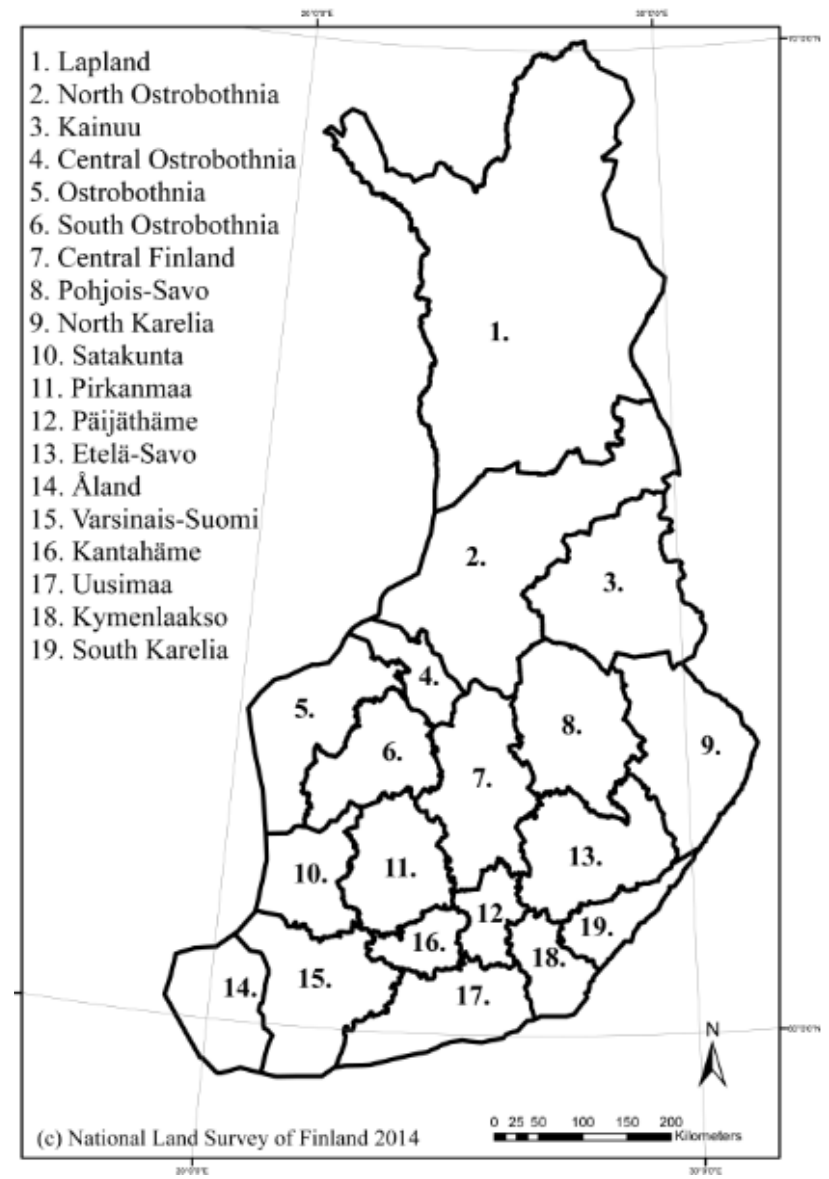

Fig. 2 - Finnish regions used in the spatial classification of current peat production areas (C) NLS, 2014).

We visualized the risk of acidification on the cutaway lands by using maps produced by the Geological Survey of Finland (GTK). The maps visualize the various probabilities (from low risk 
to high risk) of acid sulfate soils; in this study, even low-risk areas were included. The same tools (Intersection, Calculate Areas, and Summarize) were used to calculate peat production land in sulfur-rich areas by region. Sulfur-rich areas must be investigated before agricultural actions, since the oxidation of sulfur can cause soil acidification in cutaway areas [12]. Differences in local hydrology or boulder-rich areas were not included.

Finally, Kernel Density (in the Spatial Analysis tools) was analyzed with ArcMap to identify the most intensive peat production areas in Finland. First, separate peat production areas were converted into points with the Feature to Point tool. The raster size in the Kernel Density analysis was $1 \mathrm{~km}$, and the search radius was $50 \mathrm{~km}$. Each kernel was weighted by the peat production area size. The methodology is illustrated in Fig. 3.

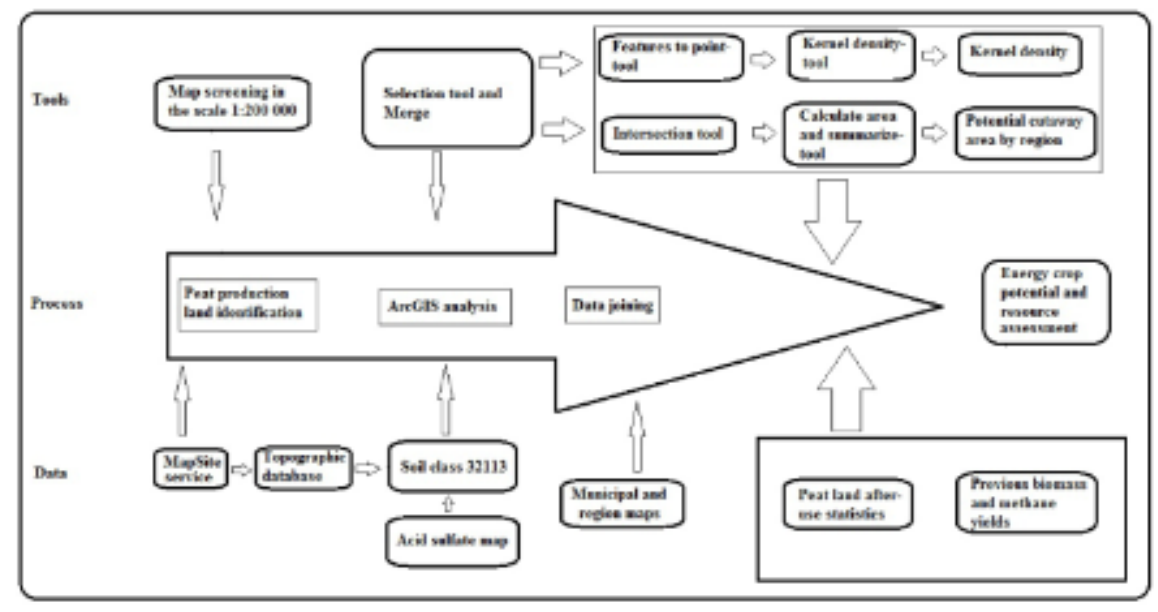

Fig. 3 - Description of the GIS methodology used to plan land use for biogas energy crop production in the case study.

\subsection{Energy crop biomass estimation}

The suitability of peat production areas for growing energy crops was estimated based on previous studies on cutaway land suitability for agricultural purposes. The value used in this 
analysis was 30\% (Eq. 1); in practice, approximately 30\% of the cutaway areas were used for energy crops and agriculture in 2010 [17]. A previous study presented theoretical values, based on mineral sub-soils, in the same scale (26-42\%) [16]. This study relies on the near-future scenario in which every current peat production area will be in the after-use phase after 30 years. The linear percentage of current peat production land exhausted by year can be justified because according to Flyktman [14], the need for new peat production areas is close to linear in Finland. Consequently, it can be assumed that cutaway areas are released from production in direct proportion. The future peat production area (size not yet established) was not assessed in this study.

Ditch loss was calculated based on $2.5 \mathrm{~m}$ ditch width (including $0.5 \mathrm{~m}$ ditch bank on both sides), because ditches are not visible in soil class 32113 (Eq. 2). Biomass yield and methane potential were calculated based on Eqs. 3 and 4. The plant-dependent biomass yield and the methane potential were calculated based on biomass yields of $5 \mathrm{Mg}_{\mathrm{dry}} \mathrm{ha}^{-1}$ and $4 \mathrm{Mg}_{\mathrm{dry}} \mathrm{ha}^{-1}$ and methane yields of 214 and $311 \mathrm{~m}^{3} \mathrm{Mg}_{\mathrm{dry}}{ }^{-1}$ for timothy-fescue grass mix and RCG, respectively. All yields are unpublished field data. Unpublished data were used because the results supported well previous studies on methane and biomass yields $[3,22,27,28]$.

Equations used in this study:

Area for energy crops by region, TAE:

$$
\text { Area by region }(\text { ha }) \times 30(\%)
$$

Ditch loss per hectare, DL (\%):

$$
500(\mathrm{~m}) \times 2.5(\mathrm{~m}) / 10000\left(\mathrm{~m}^{2}\right) \times 100(\%)
$$


Biomass yield, BY (TS):

Plant-dependent biomass yield $\left(M g_{d r y} h a^{-1} y r^{-}\right)^{1} \times T A E \times(100 \%-D L)$

Biogas gross energy yield, BP:

Plant-dependent methane yield $\left(m^{3} \mathrm{Mg}_{d r^{-1}}\right) \times \mathrm{BY} \times 10(\mathrm{kWh})$

\section{Results}

The spatial density of the current peat production in Finland and the area suitable for growing energy crops was studied using the ArcGIS program, previous studies on methane and biomass yields, and after-use statistics. There are nearly 100,000 ha of peat production land in Finland, and almost 2,900 geographically separate peat production units (or soil class 32113) were found in this study, with an average size of 34 ha. The biggest area was almost 700 ha and the smallest just a few square meters. The median size was 17 ha. The most intensive areas for producing peat are the central and western regions of Finland, and the South Ostrobothnia and North Ostrobothnia regions account for almost $45 \%$ of the total peat production area (Fig. 4). 

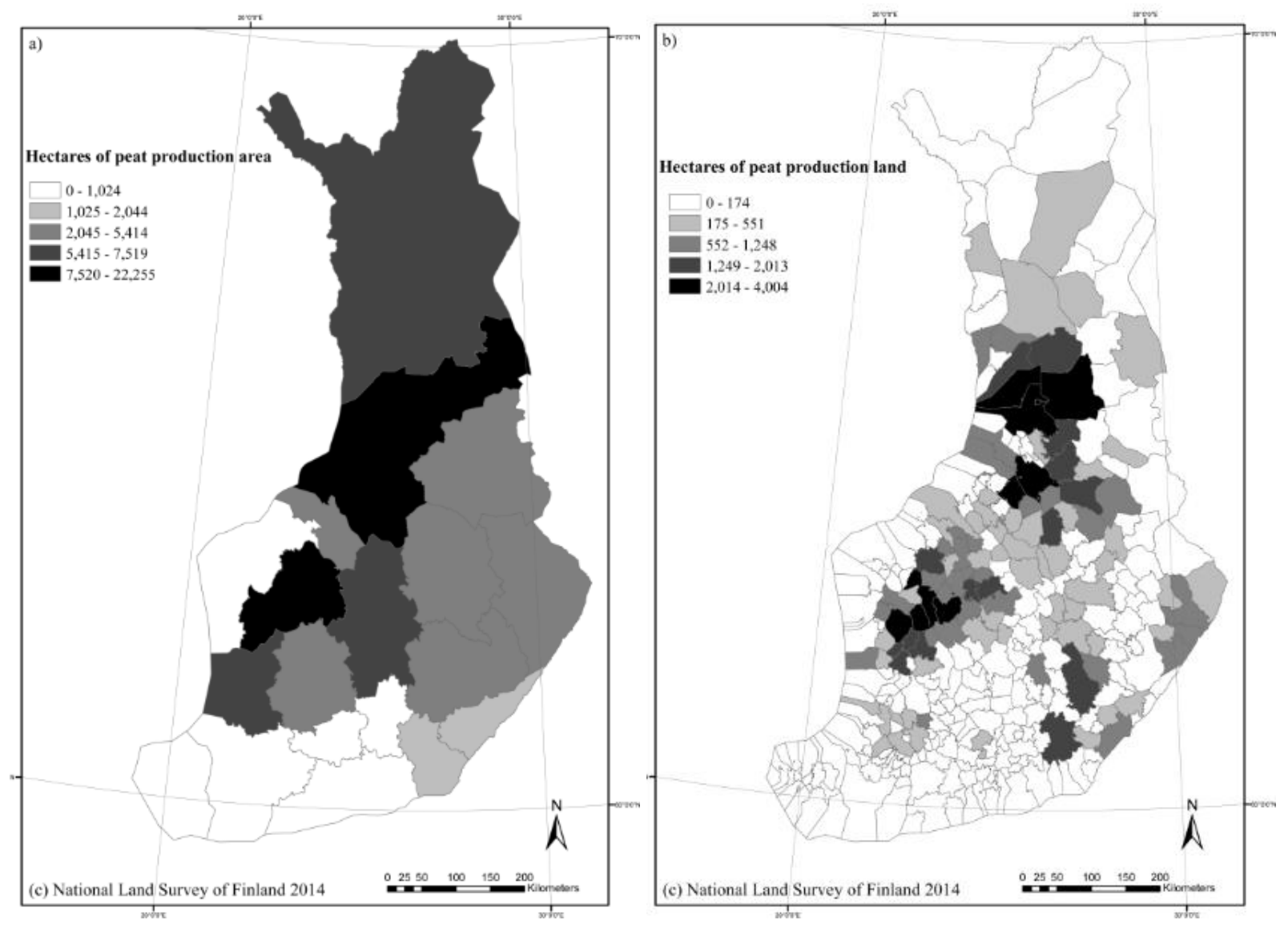

Fig. 4 - Current peat production in Finland by region (a) and municipality (b). The darker the color, the denser the peat production area (C NLS, 2014).

Kernel density was estimated to identify peat production density (Fig. 5). The densest peat production is in South Ostrobothnia, and the intensity is clearly emphasized in the western region of the country. Four areas are under especially intensive peat production: North Satakunta and southwestern parts of South Ostrobothnia, East Ostrobothnia and the northwestern parts of Central Finland, the western part of North Ostrobothnia, and the northwestern part of North Ostrobothnia and the southwestern part of Lapland. 


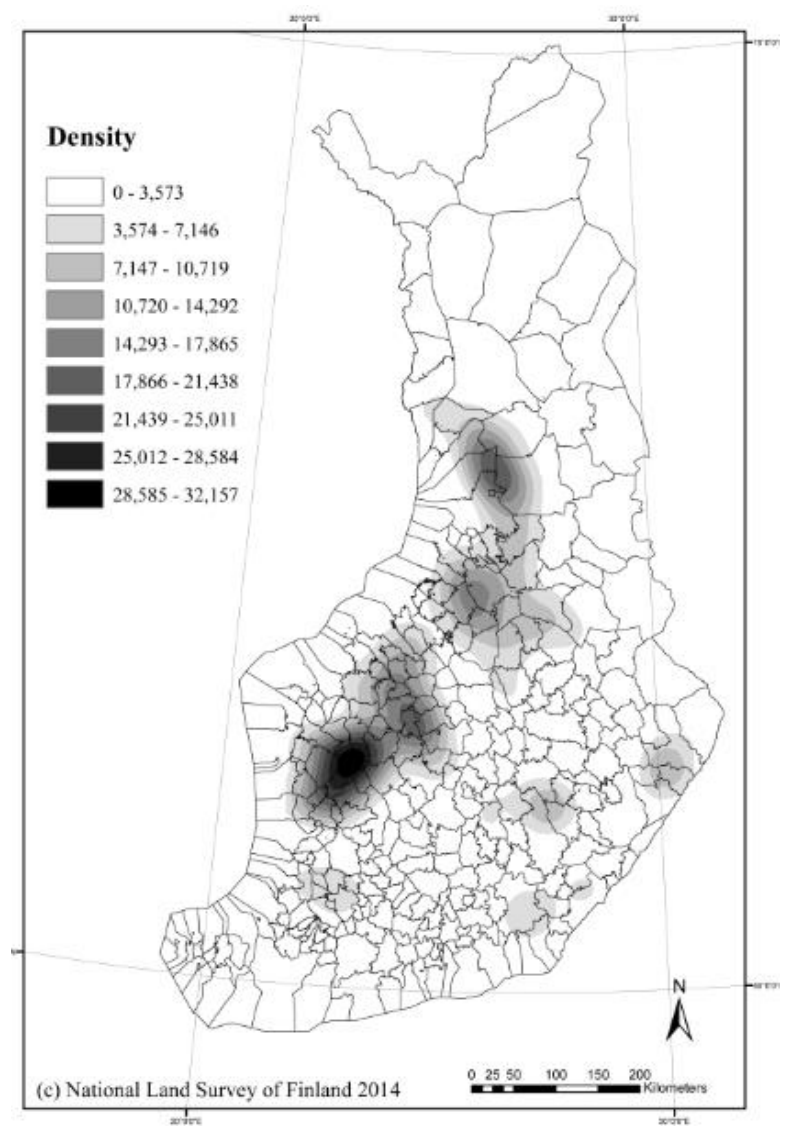

Fig. 5 - Kernel density estimation for peat production in Finland was weighted by area size. The search radius was $50 \mathrm{~km}$. The color illustrates the relative density only, not specific units (C) NLS, 2014).

The area suitable for future energy crops was then identified by using geographic information and after-use statistics. Nearly 30,000 ha of peatland theoretically could be used to grow biomass for bioenergy by 2044 (Table 1). South and North Ostrobothnia will have 6,500 and 6,700 ha, respectively, by 2044, and about 2,000 ha areas can also be found in the Central Finland, Satakunta, and Lapland regions. If the area is used for grass, either RCG or timothy-fescue, annually about $100,000 M g_{d r y}$ biomass yield could be produced with both plant species assuming two harvests per year, respectively, in Finland. This means the gross methane potential is approximately $300 \mathrm{GWh}$ per year. 
The peat production areas in acid sulfate soils were identified by using GIS-based data (Fig 6). Most of the acid sulfate peat production soils are located in the western region and especially near the coastline of the Baltic Sea. Many of the areas under intensive peat production are at risk of soil-related acidification. For instance, there are thousands of hectares of such land in South and North Ostrobothnia (Table 2).

Because peat production land is released from production section by section, a future scenario for energy crop was created. The exhaustion process for peat is long. Therefore, for the next 1020 years, only $10,000-20,000$ ha of the total area (30,000 ha) could be usable for energy crops (Fig. 7). 
Table 1 - Peat production area in 2014 (@ NLS, 2014), future cutaway lands suitable for energy crops, and annual dry biomass and methane yields after 30 years in Finland.

\begin{tabular}{|c|c|c|c|c|c|c|c|}
\hline \multirow[b]{2}{*}{ Region } & \multirow{2}{*}{$\begin{array}{l}\text { Peat production, } \\
\text { ha }\end{array}$} & \multirow{2}{*}{$\begin{array}{l}\text { Suitable for } \\
\text { energy crops, ha }\end{array}$} & \multirow{2}{*}{$\begin{array}{l}\% \text { of all of } \\
\text { the energy } \\
\text { crop area }\end{array}$} & \multicolumn{4}{|c|}{$\mathrm{CH}_{4}$ potential $\left(2\right.$ cuts $\left.\mathrm{a}^{-1}\right)$} \\
\hline & & & & RCG, $\mathrm{Mg} \mathrm{a}^{-1}$ & $\begin{array}{c}\text { RCG, GWh } \\
\mathbf{a}^{-1} \\
\end{array}$ & $\mathrm{~T}-\mathrm{F}, \mathrm{Mg} \mathrm{a}^{-1}$ & T-F, GWh $\mathbf{a}^{-1}$ \\
\hline Uusimaa & 281 & 84 & 0.3 & 295 & 1 & 369 & 1 \\
\hline Varsinais-Suomi & 1,024 & 307 & 1.0 & 1,075 & 3 & 1,344 & 3 \\
\hline Kantahäme & 858 & 257 & 0.9 & 901 & 3 & 1,126 & 2 \\
\hline Päijäthäme & 246 & 74 & 0.2 & 258 & 1 & 323 & 1 \\
\hline Kymeenlaakso & 1,898 & 569 & 1.9 & 1,993 & 6 & 2,491 & 5 \\
\hline Satakunta & 7,519 & 2,256 & 7.6 & 7,895 & 25 & 9,869 & 21 \\
\hline Central Finland & 7,479 & 2,244 & 7.6 & 7,853 & 24 & 9,817 & 21 \\
\hline Etelä-Savo & 3,353 & 1,006 & 3.4 & 3,521 & 11 & 4,401 & 9 \\
\hline North Karelia & 4,289 & 1,287 & 4.4 & 4,503 & 14 & 5,629 & 12 \\
\hline Pirkanmaa & 4,452 & 1,336 & 4.5 & 4,675 & 15 & 5,844 & 13 \\
\hline South Karelia & 2,044 & 613 & 2.1 & 2,147 & 7 & 2,683 & 6 \\
\hline Ostrobothnia & 687 & 206 & 0.7 & 722 & 2 & 902 & 2 \\
\hline $\begin{array}{l}\text { Pohjois-Savo } \\
\text { South }\end{array}$ & 5,414 & 1,624 & 5.5 & 5,685 & 18 & 7,106 & 15 \\
\hline $\begin{array}{l}\text { Ostrobothnia } \\
\text { Central }\end{array}$ & 21,802 & 6,541 & 22.1 & 22,892 & 71 & 28,615 & 61 \\
\hline $\begin{array}{l}\text { Ostrobothnia } \\
\text { North }\end{array}$ & 3,497 & 1,049 & 3.5 & 3,672 & 11 & 4,590 & 10 \\
\hline Ostrobothnia & 22,255 & 6,677 & 22.6 & 23,368 & 73 & 29,210 & 63 \\
\hline Kainuu & 5,016 & 1,505 & 5.1 & 5,267 & 16 & 6,583 & 14 \\
\hline Lapland & 6,409 & 1,923 & 6.5 & 6,729 & 21 & 8,412 & 18 \\
\hline Åland & 0 & 0 & 0.0 & 0 & 0 & 0 & 0 \\
\hline Totally & 98,524 & 29,557 & 100.0 & 103,451 & 322 & 129,313 & 277 \\
\hline
\end{tabular}

Acid sulfate soil was not considered when suitability for energy crops was calculated.

$\mathrm{RCG}=$ Reed canary grass, dry biomass yield assumption $4 \mathrm{Mg} \mathrm{a}^{-1}$ (two harvests)

$\mathrm{T}-\mathrm{F}=$ Timothy-Fescue grass, dry biomass yield assumption $5 \mathrm{Mg} \mathrm{a}^{-1}$ (two harvests 


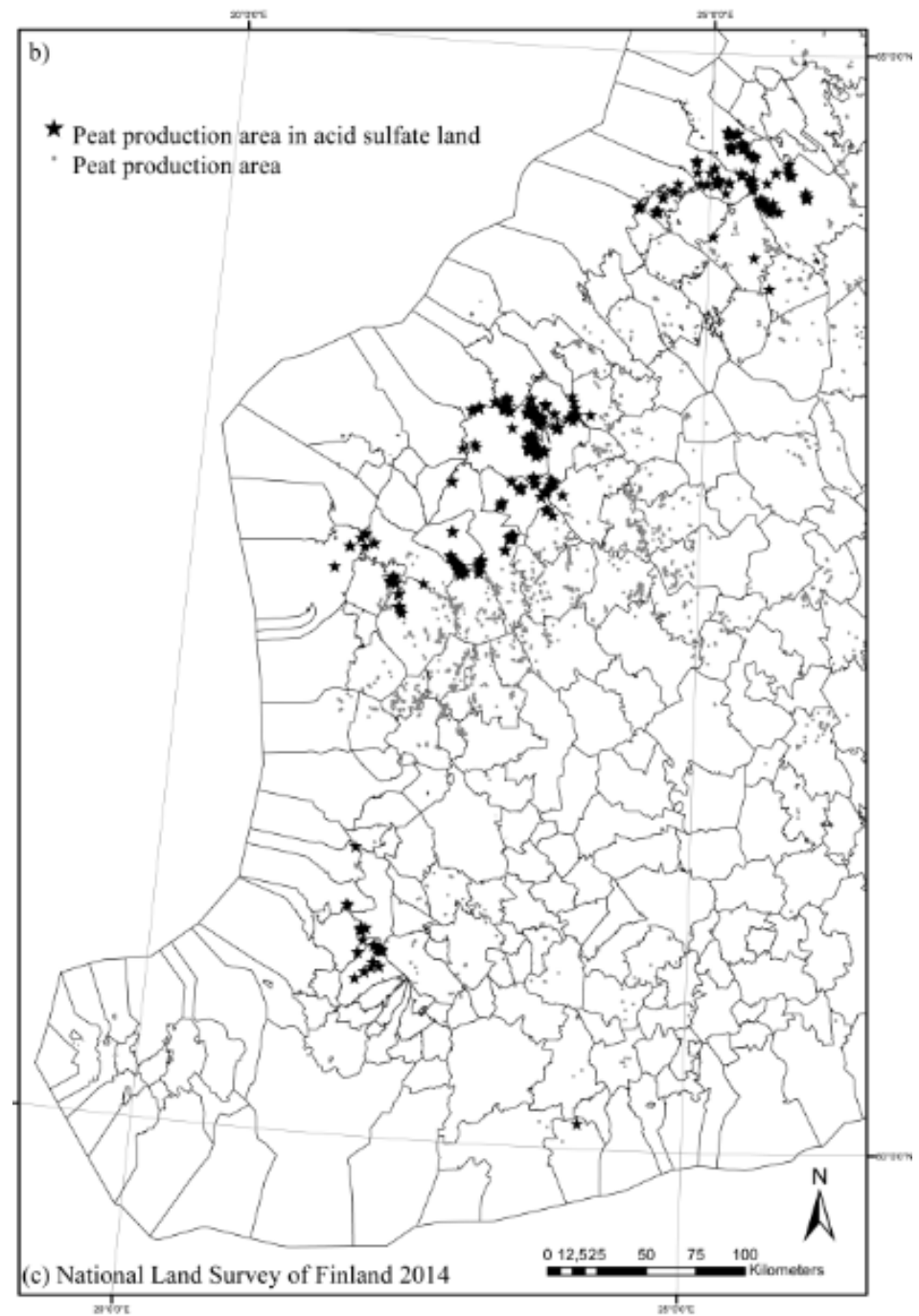

Fig. 6 - Current peat production areas in acid sulfate soil in Finland (C NLS, 2014).

Table 2 - Current peat production area under acid sulfate soils by region in Finland.

\begin{tabular}{lc}
\hline \hline Region & Peat production area under \\
\hline Uusimaa & 31 \\
Varsinais-Suomi & 300 \\
Satakunta & 171 \\
Ostrobothnia & 486 \\
South Ostrobothnia & 4,994
\end{tabular}


Central Ostrobothnia

North Ostrobothnia
2

3,806

9,791

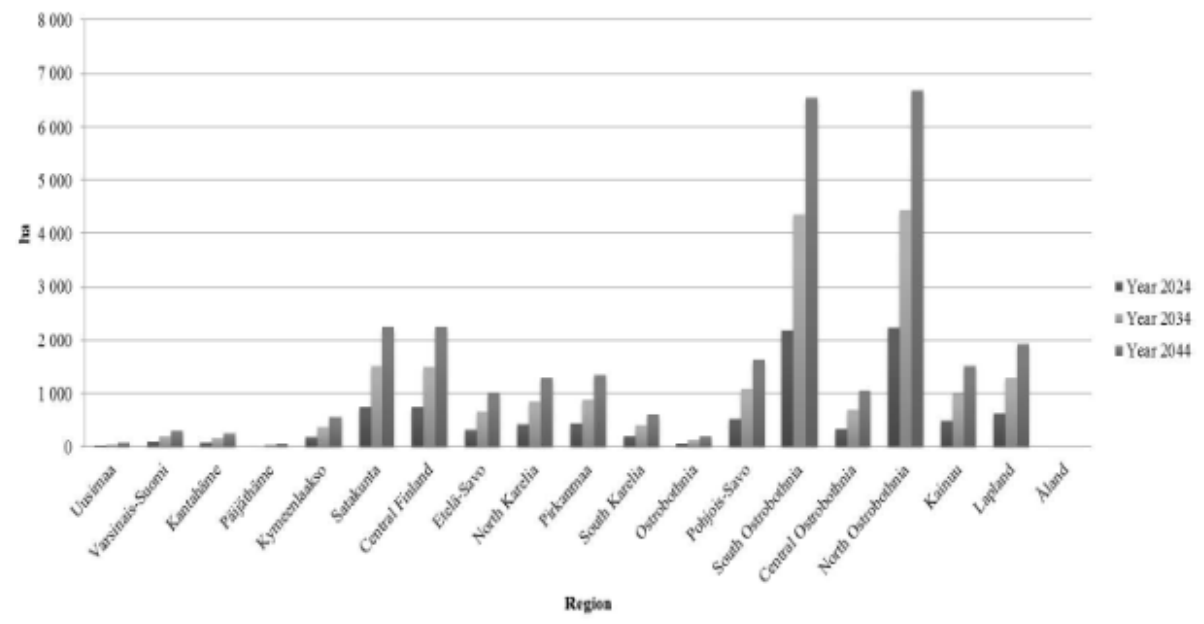

Fig. 7 - The estimated cutaway area released for energy crop production by region in Finland in the next 30 year

\section{Discussion}

In this study, significant amounts of wasteland, cutaway peat production lands, were identified for energy crops with a GIS-based method. This method was useful for recognizing peat 
production lands and assessing the near-future potential for energy crops. GIS can provide precise knowledge about spatially distributed attributes. However, the GIS method had several limitations: data availability and resolution. The same type of limitations were observed in other GIS-based bioenergy studies by Stork et al. [35] and Abolina et al. [6]. Consequently, this method is suitable only for assessing large-scale resources. The result is a coarse estimate of the after-use potential of the peat production areas for agriculture purposes in the near future, because differences in local hydrology or boulder-rich areas were not included. The most significant factor in the after-use of cutaway land is hydrology, because agriculture is not possible in wet fields. In addition, boulders and pool-forming sites, including hard silt, can be found in many mires, and every peat production site has unique geography [16]. This will affect the accuracy of the analysis. Therefore, this method targets the locations with the most potential, but we must conduct future studies on a smaller geographic scale. In this study, limitations were related to the calculations and simplifications that made assessing the technical and practical feasibility for all of Finland difficult. For example, the release or exhausted time of the peat production sites is not constant because it depends on weather conditions, the demand for the peat, and the value of other energy resources [14]. Nonetheless, peatland exhausted time points can be included in the GIS-based method.

The results of this study can be used to inform landowners and local farmers to support regional energy crops and to develop energy entrepreneurship. According to Salo and Savolainen [12], the landowner is always the final decision-maker regarding the after-use method. The choice is often related to location. If the cutaway land is near farms, the biggest possible amount of cutaway land is most likely chosen for agricultural use [26]. Different after-use methods compete with each other, and the most popular method, forestation, might be an attractive choice for 
many landowners because the annual management costs can be lower in forest management than in agriculture. Instead of forestation, the energy crop resource found in cutaway areas could play a significant role in the biogas production plans for some rural areas. In some areas, energy crops in cutaway areas have a significant effort on the regional bioenergy potential.

According to Peura and Hyttinen [37], the biogas potential of South Ostrobothnia is $609 \mathrm{GWh}$ annually if manure and RCG from fallow land are included. According to this study, an additional 71 GWh can be achieved in South Ostrobothnia if cutaway peatlands are used to grow RCG and the biomass used in biogas production in the near future (unpublished laboratory experiment). South Ostrobothnia has been a traditional peat production area because of the large peat reservoirs and peat demand of nearby cities [10]. There are still uncertainties in the total methane potential because the variability shown in previous studies is large; for example, the methane potential of RCG varies from 246 to $430 \mathrm{dm}^{3} \mathrm{~kg}^{-1} \mathrm{VS}$ [2,27,28]. Consequently, the methane potential of RCG in Finland could vary from 234 to 408 GWh annually even if the biomass yield is the same. As a comparison, the potential for Finnish biogas only in agriculture

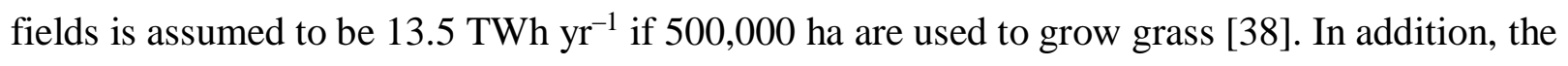
biomass yield per hectare itself is a very sensitive aspect of biogas potential and yield.

The potential of energy crops on cutaway lands is emphasized in the western region of Finland. In southern Finland, the lack of peat production is a result of naturally low peatland intensity. However, climatic and economic circumstances (e.g., cool climate, low population density, and large transportation distances) limit peat production and energy crops in northern Finland, even though the peatland intensity is high [8]. These factors can have negative effects on energy crop production. Spatial circumstances were not analyzed in this study (except acid sulfate areas), and the estimate was based on after-use statistics. The statistics apply to all geographic locations. 
This study supports a previous study conducted by Leinonen [39] on the spatial distribution of peat production by region. The amount of peatland under peat production is much higher in this study compared to the official peat production statistics when the area is calculated by using soil class 32113 . The area, with class number 32113 , is more than 98,500 ha, and officially, the area currently used for peat production is approximately 70,000 ha in Finland [9]. The difference between these values is caused by the fact that many cutaway areas are still waiting for after-use or they are support areas (out of production, roads, storage, buildings, etc., within the peat production areas), which will decrease the efficient production area. In this study, it was not possible to identify unique after-use or why different areas were still under soil class 32113 . In Finland, soil class 32113 includes other organic mining activities, such as organic soil mining for domestic use, but the area is meaningless compared to peat production. More than 300 areas total less than 1 ha each (which are most likely organic mining activities other than peat production), but the total area was only 100 ha. However, only 650 units of peat production areas larger than 50 ha were observed; the total area was 66,000 ha, which is $67 \%$ of the total peat production area in Finland. In that sense, the Kernel density estimation, which was weighted by area size, gives a starting point for assessing the biomass potential for future farm-scale biogas plants. The peat production unit size is essential when profitability is assessed, because the bigger the area, the smaller the logistics costs [12].

The question of after-use methods for cutaway peatlands is important in Finland since the amount of peat production by country is the highest in the world. For example, in 2010 cutaway areas were assumed to be 5,000 ha and 18,000 ha in Sweden and Estonia, respectively, but the area under peat production was much smaller than in Finland [40]. These countries share somewhat similar climatic conditions, peat production dynamics, peat harvesting techniques, and 
after-use choices, but the biggest amount of cutaway area is located in Finland [41]. The challenge is to improve awareness of growing energy crops on cutaway areas for biogas because large-scale cultivation and use of RCG in combustion plants have decreased rapidly in Finland. Many things support the overall sustainability of energy crops in cutaway areas, such as reduction of greenhouse gas emissions [24,25] and rapidly decreased erosion of peat from the surface of the mire [41].

Consequently, more research is needed to study landowners' willingness to choose agriculture as an after-use method. Many peat production areas are situated in remote locations, which affects cost-effectiveness. More research is also needed to improve the assessments on a local scale, for instance, with case studies based on one or a few known peat production areas. The accuracy of this type of study could be improved by using soil analysis methods and groundwater levels.

\section{Conclusions}

GIS-based methods were used in this study to promote the use of wastelands for decentralized bioenergy production. Cutaway peat production land was used as a case study. The method was useful for allocating wastelands for bioenergy production but has data resolution and simplification limitations. The GIS-based method showed that almost 100,000 ha of peat production land existed in 2014 in Finland. If $30 \%$ of the current peat production land is suitable for energy crops after 30 years, almost 30,000 ha theoretically could be used for energy crops. Approximately $45 \%$ of the peat production lands are located in South and North Ostrobothnia, and there the future potential for using cutaway areas for farming is the biggest. The densest peat production by region is in South Ostrobothnia, which could have a significant potential to use 
cutaway peat production lands for bioenergy production in farm-scale biogas plants. However, almost 5,000 ha of peat production lands in the region are under acid sulfate soils, which must be considered, even though the after-use method is not regulated by law.

Previous studies and field experience have shown that the biomass yields of RCG and timothyfescue-grass could be more than 100,000 $\mathrm{Mg}_{\mathrm{dry}} \mathrm{yr}^{-1}$ on cutaway lands in Finland by 2044 for both plant species. This means about a $300 \mathrm{GWh}$ gross energy yield with biogas technology. Cutaway peatlands can have a significant effect on creating new biogas plants and supporting decentralized energy system development in rural areas in Finland. There are still challenges, such as landowners' interests and logistical arrangements, to overcome before cutaway peat production lands can be used for biogas production in practice.

\section{Acknowledgements}

This study was funded by the ELY (Centre for Economic Development, Transport and the Environment) centers of South Ostrobothnia and Central Finland via the Drop in the Sea project. The Drop in the Sea project was conducted in collaboration with the University of Vaasa, Vaasa University of Applied Sciences and Novia. In addition, the Department of Chemistry, University of Jyvaskyla is acknowledged for financial support. Special thanks to Päivi Picken, Hannu Salo from The Bioenergy Association of Finland, Asta Harju and Samu Valpola from GTK, and Olli Reinikainen, Antti Ala-Fossi, and Marjukka Kautto from Vapo, who provided practical knowledge about peat production dynamics and after-use methods and regimes. 


\section{References}

[1] Robbins MP, Evans G, Valentine J, Donnison IS, Allison GG. New opportunities for the exploitation of energy crops by thermochemical conversion in Northern Europe and the UK. Prog Energ Combust 2012;38:138-55.

[2] Lehtomäki A, Viinikainen TA, Rintala JA. Screening boreal energy crops and crop residues for methane biofuel production. Biomass Bioenerg 2008;32:541-50.

[3] Murphy J, Braun R, Weiland P, Wellinger A. [Internet]. Biogas from crop digestion. Task 37 - Energy from Biogas. IEA Bioenergy; 2011. [cited 2015 May 13]. Available from: http://www.iea-biogas.net/files/daten-redaktion/download/publitask37/Update_Energy_crop_2011.pdf

[4] Das S, Priess JA, Schweitzer C. Biofuel options for India-perspectives on land availability, land management and land-use change. J Biobased Mater Bio 2010;4:243-55.

[5] Mola-Yudego B, Dimitriou I, Gonzalez-Garcia S, Gritten D, Aronsson P. A conceptual framework for the introduction of energy crops. Renew Energ 2014;72:29-38.

[6] Abolina E, Volk TA, Lazdina D. GIS-based agricultural land availability assessment for the establishment of short rotation woody crops in Latvia. Biomass Bioenerg 2015;7:226-72. [7] World Energy Council [Internet]. WEC Survey of Energy Resources 2013.World Energy Resources: Peat. [cited 2015 Jan 9]. Available from: http://www.worldenergy.org/wpcontent/uploads/2013/10/WER_2013_6_Peat.pdf

[8] Virtanen K. Peat resources in Finland. In: Korhonen R, Korpela L, Sarkkola S, editors. Finland - Fenland: Research and sustainable utilization of mires and peat. Finnish Peat Land Society. Maahenki Ltd; 2008, p. 29-31. 
[9] ELY (Centre for Economic Development, Transport and the Environment). Statistics for Finnish peat production area 2014.

[10] Savolainen V, Silpola J. Energy from peat. In: Korhonen R, Korpela L, Sarkkola S, editors. Finland - Fenland: Research and sustainable utilization of mires and peat. Finnish Peat Land Society. Maahenki Ltd; 2008, p. 176-88.

[11] Statistics Finland [Internet]. Energy Statistics 2013: Total energy consumption by source. [cited 2015 Jan 8]. Available from: http://pxweb2.stat.fi/sahkoiset_julkaisut/energia2013/htm1/eng10000.htm

[12] Salo H, Savolainen V [Internet]. Turvetuotantoalueiden jälkikäyttö. - Opas alan toimijoille [After-use of peat production areas - A guide for stakeholders]. Association of Finnish Peat Industry; 2008 [Finnish]. [cited 2015 Apr 29]. Available from: http://www.turveteollisuusliitto.fi/user_files2/files/Turvetuotantoalueiden_jalkikaytto_laaja_opas _print_small.pdf

[13] Salo H. Regional Manager at the Bioenergy Association of Finland and IPS (International Peat Society) Secretariat on a part-time basis. Personal communication by phone [2015 Jan 16]. [14] Flyktman M [Internet]. Energia- ja ympäristöturpeen kysyntä ja tarjonta vuoteen 2020 mennessä. [cited 2015 Apr 29]. Research Report VTT-R-03620-07; 2007 [Finnish]. Available from: http://hameenliitto.fi/sites/default/files/energia-_ja_ymparistoturpeen_tarjonta_ja_kysynta_2020_raportin_paivitys_2009_25112009_0.pdf

[15] Nuotio E, Rautio LM, Zittra-Bärsund S, editors. Kohti happamien sulfaattimaiden hallintaa - Ehdotus happamien sulfaattimaiden aiheuttamien haittojen vähentämisen suuntaviivoiksi, Helsinki. Maa- ja metsätalousministeriö. Työryhmämuistio mmm 2009, p. 8 [Finnish]. 
[16] Picken PT. Land-use scenarios for Finnish cutaway peatlands - based on the mineral subsoil characteristics. Bull Geol Soc Finl 2006;78:106-19.

[17] Vapo [Internet]. Table: Vapon turvetuotannosta vapautuvien alueiden jälkikäyttö. [cited 2014 Dec 23]. Available from: http://www.vapoviesti.fi/index.php?id=1186\&articleId=372.

Finnish.

[18] Pahkala K. Ruokohelven kasvutapa ja kasvupaikkavaatimukset. In: Salo R, editor.

Ruokohelpiseminaari. Biomassan tuotanto pelloilla ja turvesoilla sekä käyttö energian tuotantoon [Symposium of reed canary grass-Production of biomass in the fields and at the peatlands and its use for energy production]. Jokioinen: Maatalouden tutkimuskeskuksen julkaisuja. Sarja A 39; 1998, p. 21-6 [Finnish].

[19] Parviainen T. Optimization of reed canary grass cultivation on the cutaway peatlands. The influence of geological surroundings, peat characteristics and fertilizers to the element uptake and yield of reed canary grass [dissertation]. Oulu: University of Oulu; 2007 [Finnish].

[20] Puuronen M, Mikkonen T, Käyhkö V. Experimental cultivation of energy plants (reed canary grass) on peatlands and the suitability of the bioenergy for different power plants. In: Vuosikirja 1997. Osa II Turpeen ja peltobiomassojen tuotantotekniikat. Bioenergian tutkimusohjelma. Julkaisuja 18 [The yearbook 1997. Part II. Peat and field biomass production techniques. Bioenergy Research Program. publications 18]. Jyväskylä: Jyväskylän Teknologiakeskus Oy; 1998, p. 311-6 [Finnish].

[21] Lamminen P, Isolahti M, Huuskonen A [Internet]. Turvesoiden jatkokäyttö kotieläintuotannossa [cited 2015 Apr 29]. Jokioinen: MTT:n selvityksiä 101; 2005 [Finnish]. Available from: http://www.mtt.fi/mtts/pdf/mtts101.pdf 
[22] Reinikainen O, Pahkala K, Suominen M. Reed Canary grass on cutaway peatlands. In: Finland - Fenland: research and sustainable utilization of mires and peat. Finnish Peat Land Society. Maahenki Ltd; 2008, p. 217-21.

[23] Alakangas H, Hölttä P, Juntunen M, Vesisenaho T. Energiaturpeen tuotantotekniikka: koulutusaineisto [Fuel peat production technology: The training materials]. Jyväskylä: Jyväskylän ammattikorkeakoulun julkaisuja 120; 2011 [Finnish].

[24] Järveoja J, Laht J, Maddison M, Soosaar K, Ostonen I, Mander Ü. Mitigation of greenhouse gas emissions from an abandoned Baltic peat extraction area by growing reed canary grass: lifecycle assessment. Reg Environ Change 2013;13:781-95.

[25] Kirkinen J, Hillebrand K, Savolainen I. Climate impact of the use of peatland for energy land use scenario. Espoo: VTT Tiedotteita. Research Notes 2365; 2007 [Finnish].

[26] Kautto M. Production Engineer in Vapo. Personal communication [2014 May 12].

[27] Metener Oy [Internet]. Ruokohelven biokaasutuskokeet [Biomethane experiment of reed canary grass]. Loppuraportti 4.11.2009 [cited 2015 May 28] [Finnish]. Available from:

http://www.oulunkaari.com/tiedostot/Uusiutuvaenergia/raportit/Metenerin\%20ruokohelpikoe.pdf [28] Butkute B, Lemeziene N, Kanapeckas J, Navickas K, Dabkevicius Z, Venslauskas K. Cocksfoot, tall fescue and reed canary grass: drymatter yield, chemical composition and biomass convertibility to methane. Biomass Bioenerg 2014;66:I-II.

[29] Lehtomäki A. Biogas production from energy crops and crop residues [Doctoral dissertation]. Jyväskylä: University of Jyväskylä; 2006. Jyväskylä studies in biological and environmental science 163.

[30] Batzias FA, Sidiras DK, Spyrou EK. Evaluating livestock manures for biogas production: a GIS-based method. Renew Energ 2005;30:1161-76. 
[31] Ma J, Scotta NR, DeGloriab SD, Lembob AJ. Siting analysis of farm-based centralized anaerobic digester systems for distributed generation using GIS. Biomass Bioenerg 2005;28:591-600.

[32] Vänttinen V-H. Biogas technology potential for renewable energy production and material flow management in regional scale - case Central Finland [Master's thesis]. Jyväskylä: University of Jyväskylä; 2010 [Finnish].

[33] Höhn J, Lehtonen E, Rasi S, Rintala J. A Geographical Information System (GIS) based methodology for determination of potential biomasses and sites for biogas plants in southern Finland. Appl Energ 2014;113:1-10.

[34] Huang Y, Chen C-W, Fan Y. Multistage optimization of the supply chains of biofuels. Transport Res E-Log 2010;46:820-30.

[35] Stork M, Schulte A, Murach D. Large-scale fuelwood production on agricultural fields in mesoscale river catchments e GIS-based determination of potentials in the Dahme river catchment (Brandenburg, NE Germany). Biomass Bioenerg 2014;64:42-9. [36] Murray AT. Advances in location modeling: GIS linkages and contributions. J Geogr Syst 2010;12:335-54.

[37] Peura P, Hyttinen T. The potential and economics of bioenergy in Finland. J Clean Prod 2011;19:927-45.

[38] Tähti H, Rintala J. Biometaanin ja -vedyn tuotantopotentiaali Suomessa [Biomethane and hydrogen production potential in Finland]. Jyväskylä: University of Jyväskylä. Research reports in biological and environmental sciences 90; 2010 [Finnish]. 
[39] Leinonen A, editor. Turpeen tuotanto ja käyttö. Yhteenveto selvityksistä [Peat production and use. Summary reports]. Espoo: VTT tiedotteita - Research Notes 2550; 2010 [Finnish]. [40] Vasander H, Tuittila E-S, Lode E, Lundin L, Ilomets M, Sallantaus T et al. Status and restoration of peatlands in northern Europe. Wetl Ecol Manag 2003;11:51-63.

[41] Leupold S [Internet]. After use of cutaway peatlands - an overview of options and management planning [cited 2015 June 16]. Umeå: Swedish University of Agricultural Sciences Department of Forest Ecology; 2004. Available from: http://www.gretperg.ulaval.ca/fileadmin/fichiers/fichiersGRET/pdf/Doc_generale/Stencil108.pdf 